\title{
Application of a Radio Frequency Identification System for Supporting the Performance of Motorcycle Parking in Narotama University
}

\author{
Sri Wiwoho Mudjarnako ${ }^{*}$, Tubagus Purworusmiardi ${ }^{2}$ \\ 1,2Universitas Narotama \\ sri.wiwoho@narotama.ac.id ${ }^{\star 1}$, tubagus.purworusmiardi@narotama.ac.id ${ }^{2}$
}

\begin{abstract}
The increasing number of motorcycles in Indonesia creates enormous problems because of the hectic involved; thus, parking management becomes a big challenge. The applicability and the possibility of a Radio Frequency Identification (RFID) were studied in finding the solution of this pressing issue. The study was conducted at Narotama University which is located in Surabaya, East Java. This study was expected to find solutions related to provide parking facilities using RFID method to identify motorcycles. The goal of this study is to determine the number of motorcycle vehicles which is being parked electronically to facilitate the management in organizing motorcycle in parking facilities. Hence, the management can arrange the requirement of parking system in the future. From the study, it can be concluded that RFID can make the process faster and easier so that the line can significantly be reduced and provide more user friendly system because the system will give the information about parking availability. Moreover, this RFID parking system and the software can be more reliable and secured due to more complete and accurate data in the registration process required to the users.
\end{abstract}

Keywords: Motorcycle, Parking, Radio Frequency Identification.

\section{Introduction}

Two-wheeled motorcycles have currently dominated roads in Indonesian cities, especially in Surabaya. Many people prefer to use motorcycles driven by its practicality. However, behind its practical use, the rapidly increasing number of motorcycle use causes the increasing number of accidents [1]. This motorcycle domination has also occurred in Narotama University having 2,393 students [2]. Narotama is one of the private universities located in Surabaya, East Java, Indonesia. The increasing needs from the community in obtaining higher studies make this university keep evolving and developing its buildings. The evolving and developing process will increase the number of students, employees and lecturers, and this of course will also trigger the number of vehicles parked in the University area. Those great number of vehicles have stimulated this university to increase the efficiency and capacity of its parking facilities.

The user behavior of most students using motorcycles requires more orderly, comfortable, and secured parking facilities. Furthermore, these facilities should be able to accommodate the number of female motorcycle drivers [3]. In 2013, the number of motorcycle parking capacity in Narotama was available for 200 vehicles/day. Nevertheless, in 2015, it greatly increased nearly 450 vehicles/day. To overcome the limit of motorcycle parking capacity, Narotama University sets the lecturing time schedule in some sessions, but the problem occurs when there is an academic agenda requiring all students to attend and park at the same time. This situation makes the motorcycle parking capacity not being able to accommodate parking space for motorcycles. To answer the problem, the university imposes the restriction in parking capacity with the use of Radio Frequency Identification (RFID) technology. Accordingly, Radio Frequency Identification (RFID) is used because it has several advantages and has the ability to overcome the weaknesses of the other parking systems. This research stage started from the analysis and the condition of the current parking system [4].

Finding solutions to utilizing RFID in order to provide more effective parking management in Narotama University becomes the problem of this research. Moreover, the goal of the research is to determine the benefits of using RFID parking system. The rrecommendations resulted from this research would be a valuable input for Narotama University to design policies and organizing parking management in order to obtain sufficient parking capacity for the students.

Mudjanarko, S., \& Purworusmiardi, T. (2017). Application of a Radio Frequency Identification System for Supporting the Performance of Motorcycle Parking in Narotama University. Kinetik : Game Technology, Information System, Computer Network, Computing, Electronics, and Control, 2(4). doi:http://dx.doi.org/10.22219/kinetik.v2i4.528

Paper submitted on Sept 22, 2017; Revision on October 27, 2017; Received October 30, 2017 


\section{Literature Study}

\subsection{Parking}

Parking is a temporary "not moving" state of a vehicle. In addition to above definition, some experts also give their definition of parking. One of those definitions is that all vehicles will not be able to move continuously without stopping, at some point they have to stop in shorter duration (unloaded) or stop in longer duration called "parking" [5].

The parking problem is the problem of space requirements where the provision of space in urban areas is limited by the available vacant areas and the land use of the city [6]. A proper system will help to deal with the existing parking problems. Determining a parking system in accordance with the existing conditions in a region can be a challenging task. Therefore, clarifying the existing parking marks to increase parking capacity becomes highly imperative [6]. Moreover, separating the parking space between visitors and employee is another important task [6]. Finally, proper arrangement especially during peak hours so as not to cover or obstruct vehicle circulation will also crucial [6]. The parking system is presented in the Figure 1.

\subsection{Radio Frequency Identification (RFID)}

The applications of Radio Frequency Identification (RFID) system are a common and useful in manufacturing, managing supply chain, and controlling inventory [7], but the use of RFID in parking management needs to be studied further. In 2013, Elyas Palantei described a study entitled Design-based RFID Parking Management System and obtained the results of the use of RFID providing some advantages to practical and economical uses because it can substitute the functions of parking operators. Meanwhile, the research entitled Vision-based Parking Lot Monitoring: Available Parking Space Information described that RFID can inform empty parking locations so that the users can instantly find the available parking location [8].

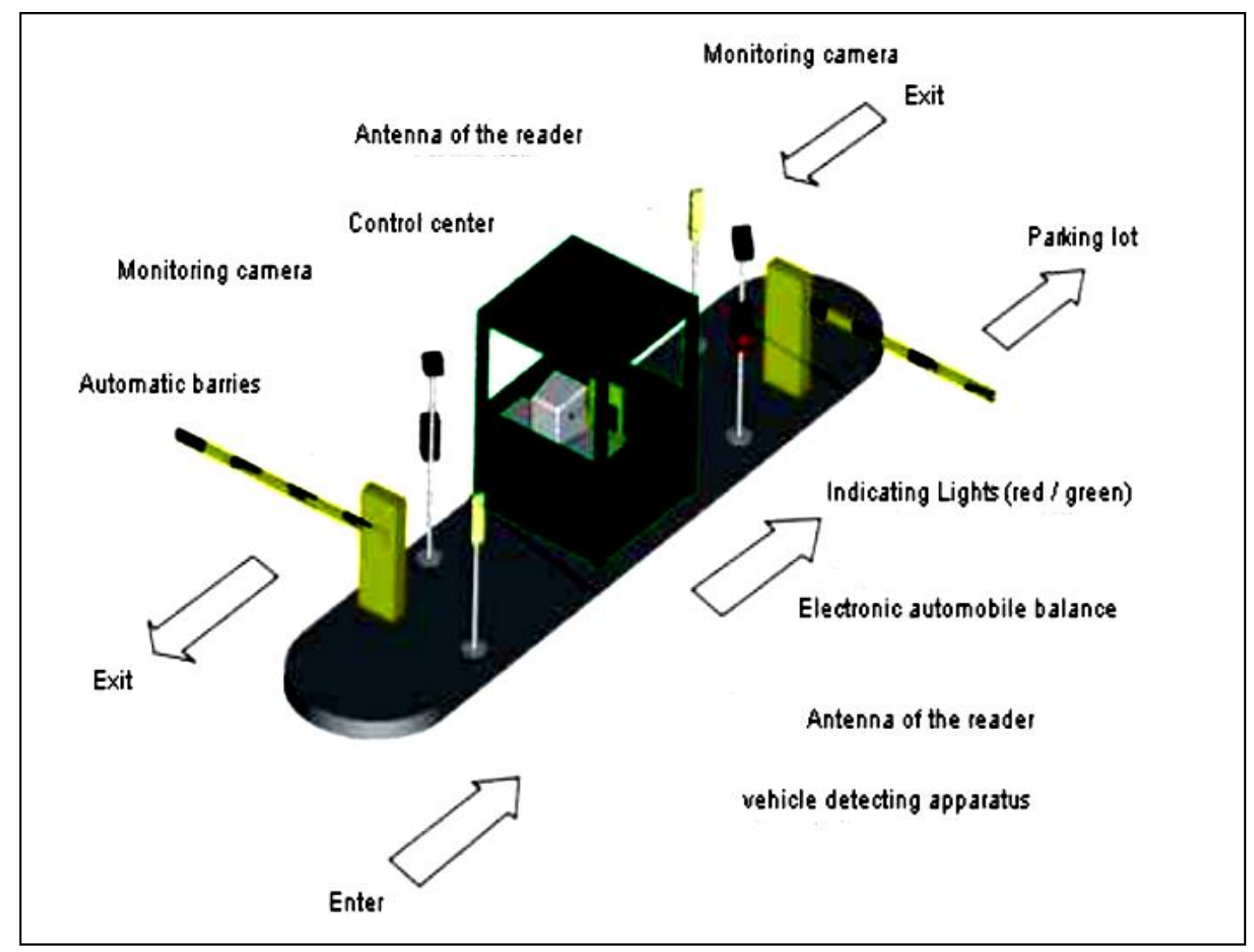

Figure 1. Parking System [9]

\section{Methodology}

The Research Methodology of this research used two phases, which are data collection phase and software development phase. 


\subsection{Method in Data Collection Phase}

Data collection phases consist of:

1. Interview

This method was completed by asking questions directly to the provider of the parking management and parking users in Narotama University

2. Literature Study

This was a method of collecting data in the form of journals, papers and readings related to the title of the study.

3. Observation

This method was carried out by directly observing and reviewing to the problems occurred in the manual parking system used in Narotama.

\subsection{Method in Software Development}

At this development stage, the researcher adopted Waterfall model as the system development life cycle method to develop the system. Waterfall model is depicted in the following Figure 2.

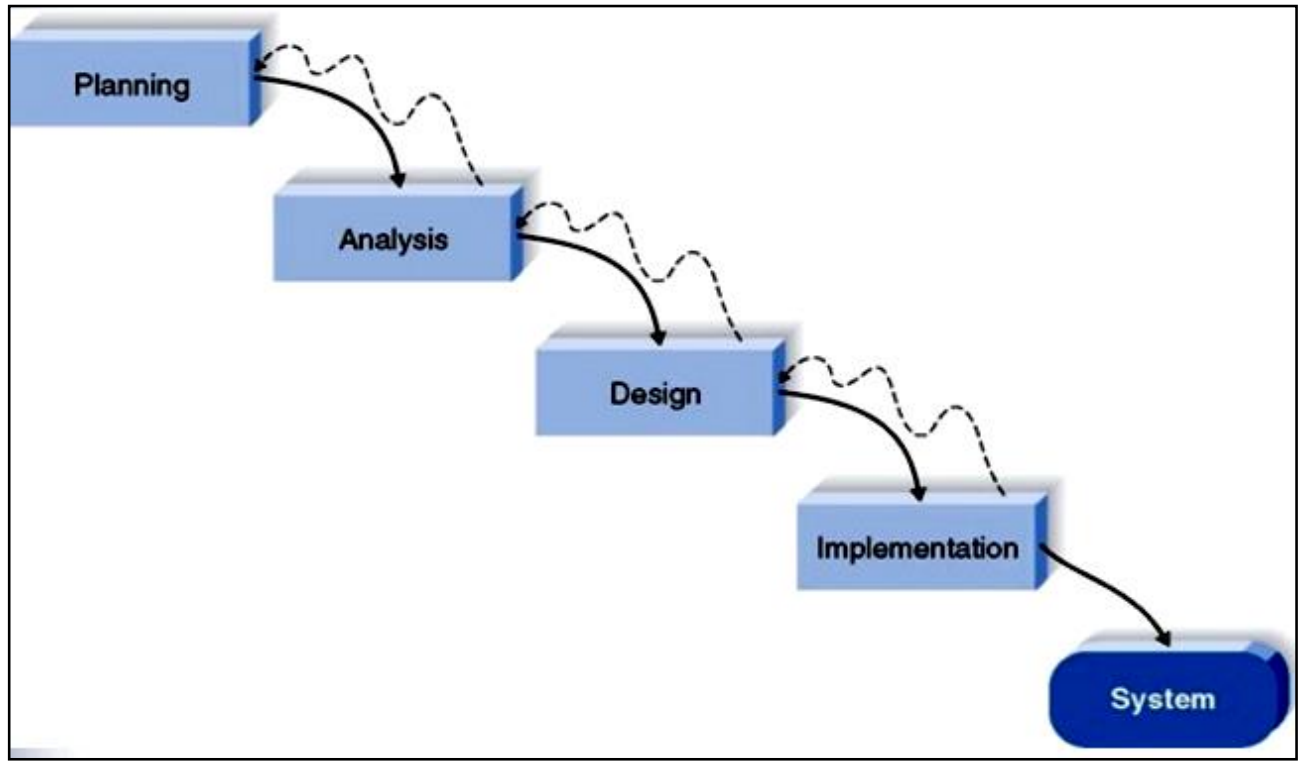

Figure 2. Waterfall Model [10]

\section{Results and discussion}

The following Figure 3 presents the design of the parking process using RFID. In this system, there are several actors involved, including the Administrators, Officers, Members and Guests reported in Figure 3, using case diagram of the parking system.

Figure 3 shows that the process of RFID parking system only needs some simple steps. While parking users are approaching the entrance, the system tells the users about quota availability of the parking area. Afterwards, the RFID scanner reads RFID user's card (the data required was already included in the student's and staff's ID cards). Finally, the system will record and process the data of vehicle entry time.

The former process that must be done to run this system is the registration process. This process requires accurate and complete data because it will affect the security of this system. By employing this accurate data recording, the users can be recognized by the RFID while they are entering the parking area. The flowchart diagram for the registration process is illustrated in the following Figure 4, and the flowchart of the parking process is presented in Figure 5.

However, as a preventative measure, in the case of missing or corrupted RFID cards, the card owners can register a new card by collecting a report to the User Administrators. After finishing the checking process and fulfilling all necessary requirements, new RFID cards can be printed and issued. The flowchart diagram for RFID card replacement process is depicted in Figure 6.

Application of a Radio Frequency Identification System for Supporting the Performance of ... Sri Wiwoho Mudjanarko, Tubagus Purworusmiadi 


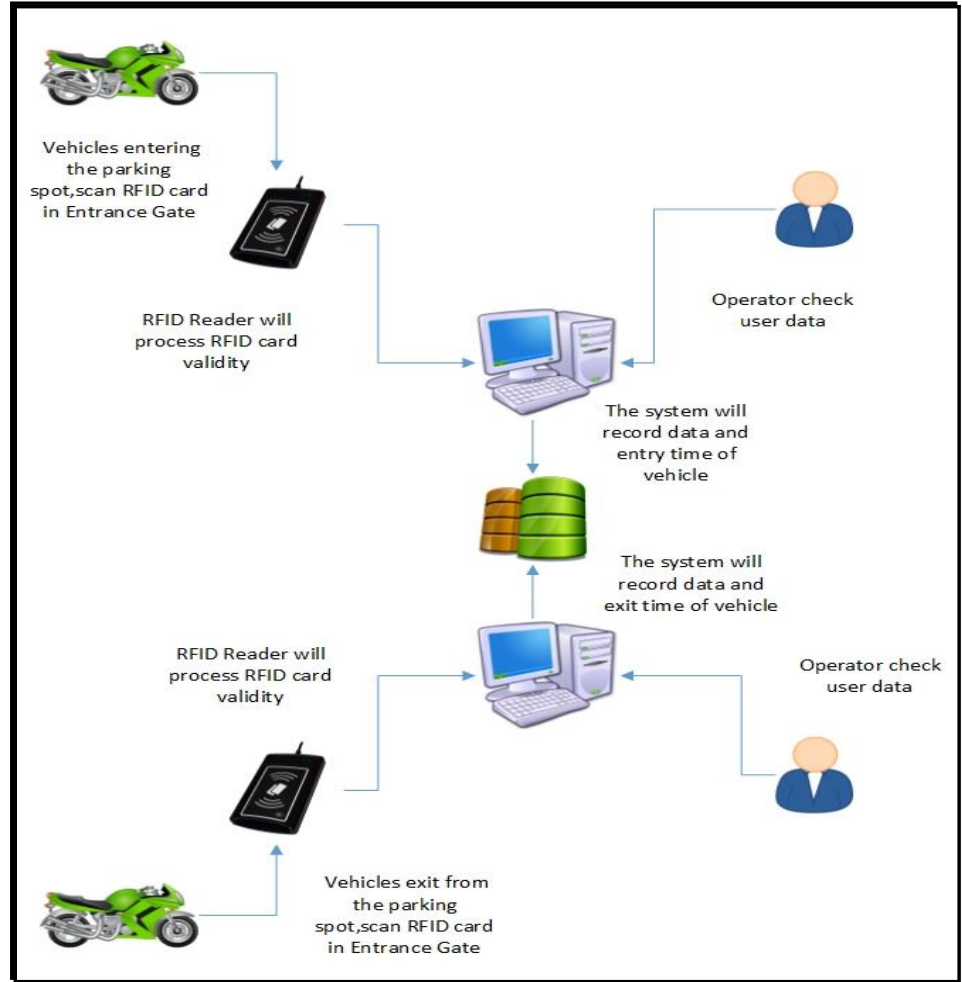

Figure 3. The Design of the Parking System Using RFID

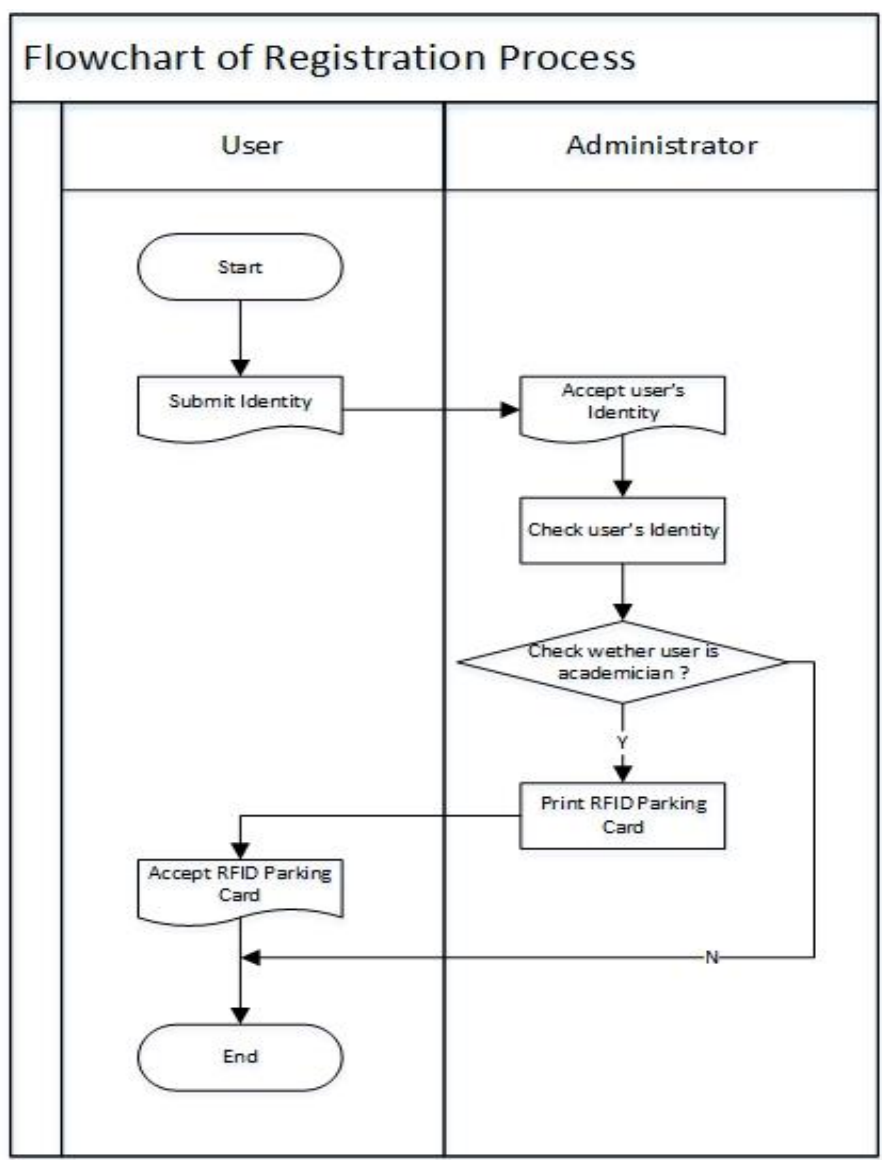

Figure 4. The Flowchart Diagram of Registration Process of RFID Parking System 


\section{Conclusion \& Recommendation}

\subsection{Conclusion}

The conclusion from this study is the parking management system using RFID technology provides three solutions, in making the parking process be more efficient: (1) the process of parking system needs only 1-3 seconds; (2) the indicator and censor are used to determine the availability of parking quota; and (3) the use of RFID will make the system more secured because the system will be able to recognize the users while they are entering and leaving the parking area. By offering these three solutions, the university will get more benefits than those of the manual or conventional systems. On the other hand, RFID uses radio waves as a medium of information exchange, this system requires minimum cost because it is compatible with almost all types of PCs and laptops.

\subsection{Recommendation}

Based on the results of study of RFID parking system utilization, it is recommended for further research in parking management system to scan police license number by a sensor to validate users' data. Moreover, having web-integrated system is strongly recommended, providing the capability to access the available quota in the parking system before entering the building.

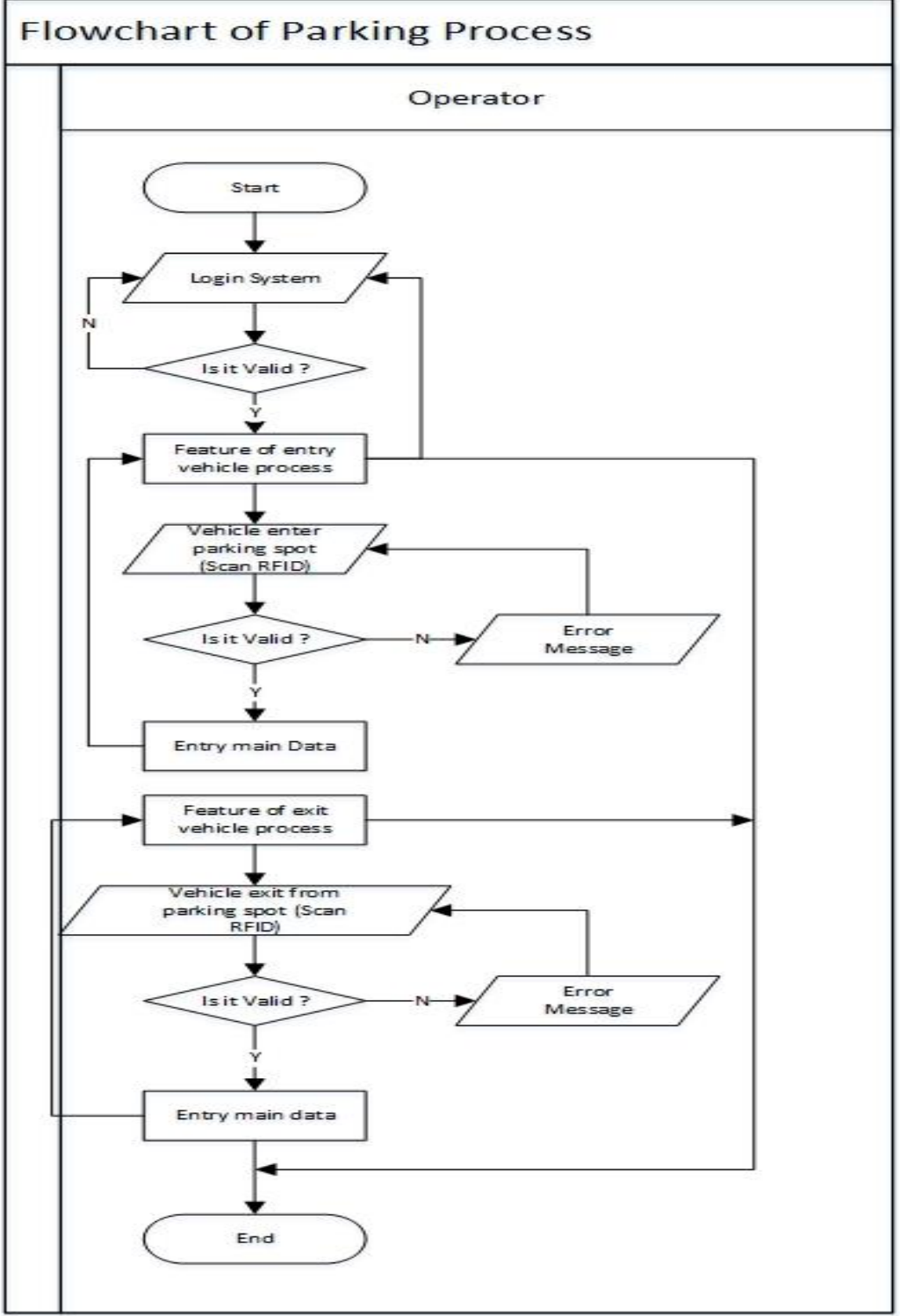

Figure 5. The Flowchart Diagram of RFID Parking System

Application of a Radio Frequency Identification System for Supporting the Performance of ... 


\section{Flowchart of Replacement Process}

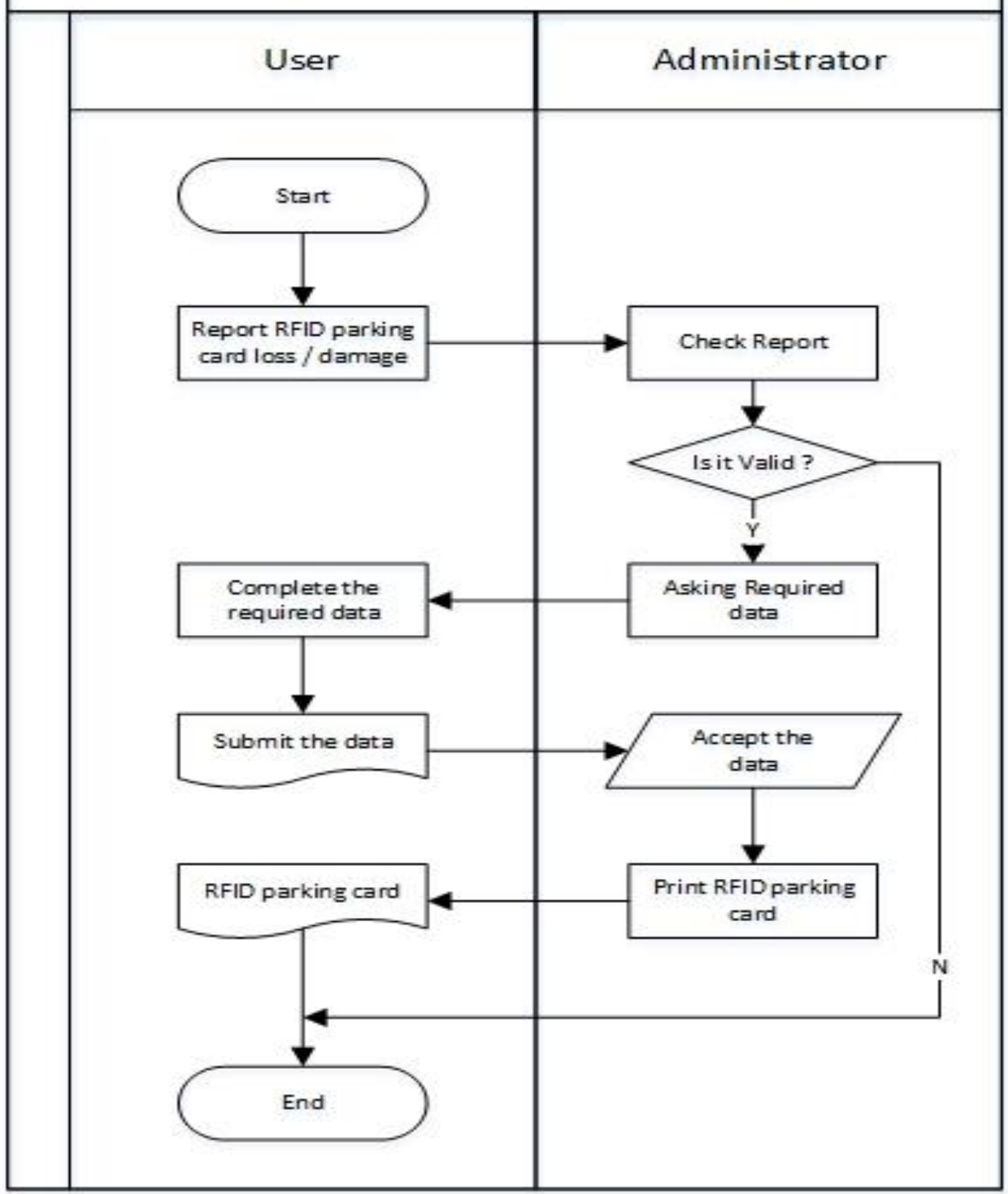

Figure 6. The Flowchart Diagram for the New RFID Card Replacement Process

\section{References}

[1] Machsus, Harnen Sulistio, A. Wicaksono, and L. Djakfar, "The Effect of Access Points on Motorcycle Accident Rates on Surabaya Arterial Roads", Australian Journal of Basic and Applied Sciences, Vol. 8, No. 10, Pp. 38-43, 2014.

[2] "Student Database of Narotama," 2016.

[Online]. Available: http://forlap.dikti.go.id/perguruantinggi/search. [Accessed: 09-Oct-2016].

[3] S. Wiwoho Mudjanarko, H. Sulistio, L. Djakfar, and A. Wicaksono, "Behaviour Model of Motor Cycle User in Selecting Parking Location (Case study in Surabaya City of Indonesia)," Journal of Basic and Applied Scientific Research, Vol. 3, No. 7, Pp. 842-846, 2013.

[4] A. D. Utama, "Design of Parking System for Four-wheeled Vehicles Using RFID Technology in Universitas Sebelas Maret," Universitas Sebelah Maret, 2010.

[5] S. W. Mudjanarko, T. P, S. P. S, and D. Harmanto, "Parking Using Model with Simulation Program in Surabaya City," in Procceding of Narotama Internasional Conceference on Civil Engineering, 2015.

[6] P. A. Suthanaya, "Analysis of Characteristics and Parking Area Requirement at the Shopping Malls in Badung Regency," Scientific Journal of Civil Engineering, Vol. 14, No. 1, 2010. 
[7] A. Bajpai, "RFID-Based Secured Parking Management System," IJSTE - International Journal of Science Technology \& Engineering, Vol. 1, No. 11, 2015.

[8] E. Palantei et al., "Development of Smart Parking System with Wed Integration," 2013.

[9] S. C. Hanche, P. Munot, P. Bagal, K. Sonawane, and P. Pise, "Automated Vehicle Parking System using RFID," ITSI Transactions on Electrical and Electronics Engineering, Vol. 1, No. 2, Pp. 2320-8945, 2013.

[10] A. Dennis, B. H. Wixom, and D. P. Tegarden, "Systems Analysis and Design with UML Version 2.0: an Object-Oriented Approach," United States of America: J. Wiley \& Sons, Inc, 2005. 
